\title{
Parental Rights in Relation to Denominational Schooling under the European Convention on Human Rights
}

\author{
Jeroen Temperman ${ }^{1}$ \\ Professor of International Law \& Religion, Erasmus School of Law, \\ Erasmus University Rotterdam, The Netherlands; Member, osce Panel \\ of Experts on Freedom of Religion or Belief
}

\begin{abstract}
Whereas the bulk of Article 2 Protocol I cases concerns aspects of the public-school framework and curriculum, this article explores Convention rights in the realm of denominational schooling. It is outlined that the jurisprudence of the Strasbourg Court generally strongly supports the rights of parents not to send their child to stateorganized schools and hence to establish or avail of private, denominational schooling instead. In this area of private schooling, the Strasbourg Court could build a stronger body of jurisprudence against discriminatory funding policies. The Court is right in seeing no state duty to fund denominational schools, but where intricate funding policies serve to privilege the state or dominant religion and their schools, at the disadvantage of minority religion schools, the Court should come into action.
\end{abstract}

\section{Keywords}

Protocol 1 ECHR - European Convention on Human Rights (ECHR) - European Court of Human Rights (ECtHR) - freedom of religion or belief - right to education children's rights - parental rights

1 This article is written in a scholarly capacity and does not represent the views of the Organization for Security and Co-operation in Europe.

(C) JEROEN TEMPERMAN, 2017 | DOI 10.1163/18710328-12231133

This is an open access article distributed under the terms of the Creative Commons Attribution 4.0

International Public License (CC-BY 4.0). https://creativecommons.org/licenses/by/4.0/.com04/26/2023 01:19:18PM 


\section{Introduction}

Article 2 of Protocol I (PI-2) to the European Convention on Human Rights (ECHR, the Convention) applies in nearly all Council of Europe member states, the two only exceptions being Monaco and Switzerland. ${ }^{2}$ The provision reads:

No person shall be denied the right to education. In the exercise of any functions which it assumes in relation to education and to teaching, the State shall respect the right of parents to ensure such education and teaching in conformity with their own religions and philosophical convictions.

Generally speaking, the clause aims, in the words of the ECtHR expressed in an early landmark case, 'at safeguarding the possibility of pluralism in education which possibility is essential for the preservation of the "democratic society" as conceived by the Convention. In view of the power of the modern State, it is above all through State teaching that this aim must be realised. ${ }^{3}$ More specifically, the European Court of Human Rights (ECtHR, the Strasbourg Court, the Court) has underscored that '[ $t$ ] he State is forbidden to pursue an aim of indoctrination that might be considered as not respecting parents' religious and philosophical convictions. ${ }^{4}$

PI-2's baseline in that regard is that 'the State, in fulfilling the functions assumed by it in regard to education and teaching, must take care that information or knowledge included in the curriculum is conveyed in an objective, critical and pluralistic manner.5 Accordingly, the main rule that flows from $\mathrm{PI}-2$ is that the state creates a public school framework-which is more than the mere content of the curriculum ${ }^{6}$ — that is designedly "neutral" rather than

2 Protocol to the Convention for the Protection of Human Rights and Fundamental Freedoms, ETs No. 9, adopted on 20 March 1952 (entry into force: 18 May 1954). A number of states have, however, made reservations to this provision or deposited restrictive interpretative declarations, including e.g. Andorra, Malta, Turkey and the United Kingdom.

3 European Court of Human Rights, Kjeldsen, Busk Madsen and Pedersen v. Denmark, Application Nos. 5095/71; 5920/72; 5926/72, judgment of 7 December 1976, para. 5 o.

4 Kjeldsen, Busk Madsen and Pedersen v. Denmark, para. 53 .

5 As held in the landmark case of Kjeldsen, Busk Madsen and Pedersen v. Denmark, para. 53; and reiterated since, e.g. in Folgerø and Others v. Norway, Application No. 15472/02, Grand Chamber judgement of 29 June 2007, para. 84(h).

6 Folgerø and Others v. Norway, para. 84(c): "That duty is broad in its extent as it applies not only to the content of education and the manner of its provision but also to the performance of all the "functions" assumed by the State'. 
denominational. That is, the state cannot use the educational framework to teach religion in ways that are not "objective, critical and pluralistic". The flipside, then, is that if teaching is in fact "objective, critical and pluralistic", then parents have no rights to assert in this area, not even if the topic of religion or belief is directly or indirectly touched upon during such teaching. In the words of the Strasbourg Court, PI-2 'does not prevent States from imparting through teaching or education information or knowledge of a directly or indirectly religious or philosophical kind. It does not even permit parents to object to the integration of such teaching or education in the school curriculum, for otherwise all institutionalised teaching would run the risk of proving impracticable. ${ }^{7}$

In the light of these general contours of PI-2, it is not surprising perhaps that the bulk of the relevant case law concerns: (i) the question whether a certain part of the curriculum or another aspect of the public educational framework is sufficiently objective, critical and pluralistic; (ii) should teaching be found not to be pluralistic enough, the question arises if and to what extent exemptions - rules facilitating pupils being opted out from the impugned teaching - may function as a safety net. A somewhat dissimilar third strand of cases concerns the residual ways for the state to respect PI-2's parental liberties, notably by permitting/accommodating — though not necessarily funding, as we will see-educational initiatives outside the public school framework.

This short article will exclusively focus on the latter-possibly least explored-issue of denominational education, while an attempt at exhaustively analysing and appraising the case-law on questions (i) and (ii), pluralistic state school teaching and exemptions to confessional teaching (in public school settings) respectively, is reserved for a separate article. ${ }^{8}$

While most PI-2 cases concern parental conscientious issues in relation to (aspects of) the public school curriculum/framework, PI-2 rights in principle also apply in the context of private schooling. ${ }^{9}$ In this regard, the ECtHR has consistently held that ' $[\mathrm{i}] \mathrm{t}$ is on to the fundamental right to education that is

7 Kjeldsen, Busk Madsen and Pedersen v. Denmark, para. 53; Folgerø and Others v. Norway, para. $84(\mathrm{~g})$.

8 The latter, comprehensive article on freedom of religion or belief and education under Protocol I is forthcoming in a book edited by Jeremy Gunn, Jeroen Temperman, and Sir Malcolm Evans (Brill, 2018, forthcoming).

9 It should be noted at the outset that not each and every of the below discussed cases was dealt with by the Strasbourg Court under PI-2, some were assessed in the light of the general 
grafted the right of parents to respect for their religious and philosophical convictions, and the first sentence [of PI-2] does not distinguish, any more than the second, between State and private teaching.'.10

That said, the duties of the state are far more modest within the private educational realm. After all, PI-2 provides that rights must be respected by the state ' $[\mathrm{i}] \mathrm{n}$ the exercise of any functions which it assumes in relation to education and to teaching' and, naturally, typically the state assumes such functions chiefly within the framework of public schooling. In the words of the Strasbourg Court, "[i]n view of the power of the modern State, it is above all through State teaching that this aim must be realised.'11

Accordingly, one way to visualise the position of PI-2 with respect to private schooling is to conceive of such schooling as an important alternative outside the realm of the public sphere (the state and its public powers) - an option, hence, that in itself helps to safeguard 'pluralism in education.' ${ }^{2}$ In other words, one important residual way of guaranteeing religious and educational rights exists in the recognition and acceptance of the possibility of not opting for state education.

Since the exact language of PI-2 itself is rather silent - this in sharp contrast to the heated debates in the travaux prépraratoires on this matter ${ }^{13}$ —on the topic of private education, some State parties wished to elaborate on this point through interpretative declarations at the time of signing the Convention. Accordingly, an interpretation deposited by Ireland reads: 'the Irish Delegate puts on record that, in the view of the Irish Government, Article 2 of the Protocol is not sufficiently explicit in ensuring to parents the right to provide education for their children in their homes or in schools of the parents' own choice, whether or not such schools are private schools or are schools recognised or established by the State.. ${ }^{14}$ Macedonia, interestingly, did the exact opposite and entered an express reservation with a view towards ruling out any right of parents under PI-2 to establish private primary schools. ${ }^{15}$ This remarkable exceptionalism had its basis in the Constitution of Macedonia

freedom of religion clause (Article $9 \mathrm{ECHR}$ ), and if the rights of schools per se are at stake, typically an Article 11 assessment is made (freedom of association).

Folgerø and Others v. Norway, para. 84 (paraphrasing similar language in the early judgment of Kjeldsen, Busk Madsen and Pedersen, para. 50. See also e.g. Hasan and Eylem Zengin v. Turkey, Application No. 1448/04, judgement of 9 October 2008, para. 48.).

11 Ibid., same paragraph numbers.

12 Ibid., same paragraph numbers.

13 See Kjeldsen, Busk Madsen and Pedersen, para. 50.

14 Declaration contained in the instrument of ratification, deposited on 25 February 1953.

15 Reservation contained in the instrument of ratification, deposited on 10 April 1997, which reads: 'the right of parents to ensure education and teaching in conformity with their 
which contains the following clause: 'Citizens have a right to establish private schools at all levels of education, with the exception of primary education, under conditions determined by law'.16

Notwithstanding such exceptions, parental rights to establish schools outside the public framework - precisely by way of residually protecting PI-2 rights - are fairly uncontested. Most outspokenly in that regard, was the former European Commission of Human Rights in an early decision, Ingrid Jordebo Foundation of Christian Schools and Ingrid Jordebo v. Sweden, in which the Commission posits that 'Article 2 of Protocol No. 1 ( $\left.\mathrm{P}_{1-2}\right)$ guarantees the right to start and run a private school. ${ }^{17}$ But also in other cases the right to opt for private instead of public education and even indeed the right to 'establish' such alternative education has been affirmatively engaged with by the Strasbourg Court. ${ }^{18}$ Moreover, this right is firmly supported by other international human rights treaties. ${ }^{19}$

The burden to actually organize and operate such alternative education lies on private individuals and not on the state. It was established early on in the jurisprudence of the Strasbourg Court, in the landmark Belgian Linguistics Case, that an individual cannot 'draw from [PI-2] the right to obtain from the public authorities the creation of a particular kind of educational establishment'. ${ }^{20}$

In a case concerning the Church of Scientology, it was moreover held that the state is not even obliged, under PI-2, to formerly recognize any particular

own religious and philosophical convictions cannot be realised through primary private education, in the Republic of Macedonia.'

16 Constitution of Macedonia, Article 45.

17 Ingrid Jordebo Foundation of Christian Schools and Ingrid Jordebo v. Sweden, Application No. 11533/85, admissibility decision of the European Commission of Human Rights of 6 March 1987, at 'The Law'.

18 See e.g. Kjeldsen, Busk Madsen and Pedersen v. Denmark, para. 54; Jiménez Alonso and Jiménez Merino v. Spain, Application No. 51188/99, admissibility decision of 25 May 2000, para. 1 of 'The Law'; and W. and D.M., M. and H.I. v. United Kingdom, Application Nos. $10228 / 82$ and $10229 / 82$, admissibility decision by the European Commission of Human Rights of 6 March 1984, at 'The Law'.

19 See Article 13, paras. 3 and 4 of the UN International Covenant on Economic, Social and Cultural Rights; Article 29 of Un Convention on the Rights of the Child, recognizing the 'the liberty of individuals and bodies to establish and direct educational institutions'. See also Art. 5, para. 1(b), of the Convention Against Discrimination in Education, of 14 December 1960, Unesco, 11th Sess., 429 U.N.T.S. 93.

20 Case Relating to Certain Aspects of the Laws on the Use of Languages in Education in Belgium, Application Nos. 1474/62; 1677/62; 1691/62; 1769/63; 1994/63; 2126/64, judgement of 23 July 1968, at section B, para. 9 . 
educational establishment. ${ }^{21}$ Also, significantly, the ECtHR has not been willing to distil from PI-2 a right to opt for home schooling. While some State parties to the Convention-sometimes even constitutionally-grant this possibility, the Strasbourg Court has deemed that there is no clear consensus among European states in this regard. In fact, many states provide for compulsory primary school education, be it public or private, but expressly excluding the possibility of home schooling, which arrangement has been sanctioned by the Court for instance in a case brought by Christian parents against Germany who wished to educate their children in accordance with the didactical and religious doctrines of the Philadelphia School (a small religious community which is, according to the complaint, strongly attached to the bible and firmly opposed to regular schools' use of, among other things, fairy-tales involving witches and dwarfs). ${ }^{22}$ In its reasoning, the Court falls back on the main rule of thumb, namely that PI-2 is dominated by the first sentence on the right to education per se. Since no person shall be denied the right to education, the German authorities' decision not to grant exemptions from compulsory schooling were justified, especially also since primary-school education is so much more than 'the acquisition of knowledge' seeing as 'integration into and first experiences of society' are among its important goals as well. ${ }^{23}$ In decisions concerning State parties to the Convention which do in principle permit home schooling, the Strasbourg Court has deemed it legitimate for the educational authorities to impose certain quality standards, to monitor those, and to take measures (including altogether overruling the entitlement to home schooling) in the face of proven quality concerns. ${ }^{24}$

But also in many other ways it can be said that this right not to opt for state schooling and hence to have one's children schooled at a private, e.g. denominational school, is not an absolute entitlement. In Ingrid Jordebo Foundation of Christian Schools and Ingrid Jordebo v. Sweden, the former Commission held that 'such a right cannot be a right without conditions. It must be subject to regulation by the State in order to ensure a proper educational system

21 C. of S. of C. v. the United Kingdom, Application No. 3798/68, admissibility decision of the European Commission of Human Rights of 17 December 1968.

22 European Court of Human Rights, Konrad and Others v. Germany, Application No. 35504/03, judgement of 11 September 2006.

23 Konrad and Others v. Germany, at 'The Law'.

24 E.g. B.N. and S.N. v. Sweden, Application No. 17678/91, admissibility decision of the European Commission of Human Rights of 30 June 1993; and Family H. v. United Kingdom, Application No. 10233.83, admissibility decision of the European Commission of Human Rights of 6 March 1984 . 
as a whole. ${ }^{25}$ The European Commission of Human Rights decided that the Swedish educational authorities' refusal to grant a denominational school permission to teach the upper stage classes (while granting such permission to teach the lower stage classes) was objective and reasonable since that decision was purely based on such quality regulations which are legitimately monitored by the state even where and when they affect the private sector (in this particular case, some of the school's teachers lacked the formal competences to teach the upper classes).

In a number of cases, compelling reasons were found by the Strasbourg Court that justified state interferes with parental choices made in this context. For instance, the applicant in Graeme v. United Kingdom complained that her son was not educated in a private, denominational school of her choice, claiming a PI-2 breach. ${ }^{26}$ Her son was mentally and physically handicapped and had, after disagreements between the applicant and the local educational authorities, been made ward of court. Having attended some state schools, the son became eventually enrolled, through interventions by the authorities, in a Steiner school. His mother claimed among other things that such a school 'discouraged ... family and Christian life.'. ${ }^{27}$ The European Commission of Human Rights' principal line of reasoning was a procedural one, concluding that the mother had 'forfeited much of her parental freedom of choice' once her son was made a ward of court. ${ }^{28}$ By way of extensive obiter dictum the Commission, however, also engaged with the merits of the complaint, reasoning that while the school in question was chiefly chosen for its good reputation for educating handicapped children, it in fact did follow Christian teachings, rendering the complaint manifestly ill-founded. ${ }^{29}$ Obviously, for a secular court to enter into such doctrinal religious matters has all the markings of skating on very thin ice.

Be that as it may, while in the latter case it was, to a significant extent, health reasons that trumped parental religious rights, in Eriksson v. Sweden the lack of guardianship per se made this PI-2 complaint baseless. ${ }^{30}$ The first applicant is the biological mother of the second applicant, who has been placed in a foster home. The mother, after theft and drugs-related convictions, 'went

25 See also Ingrid Jordebo Foundation of Christian Schools and Ingrid Jordebo v. Sweden, at 'The Law'.

26 Graeme v. United Kingdom, Application No. $13887 / 88$, admissibility decision of 5 February 1990.

27 Graeme v. United Kingdom, at 'The Facts'.

28 Graeme v. United Kingdom, at 'The Law'.

29 Graeme v. United Kingdom, 'The Law'.

30 Cecilia and Lisa Eriksson v. Sweden, Application No. 11373/85, decision of the European Commission of Human Rights of 14 July 1988. 
through a religious conversion' and became a member of the Philadelphia congregation (a Pentecostal movement). ${ }^{31}$ It is in that light that she claims that the foster parents' practice of religion-Church of Sweden members, who in the mother's view are not practising Christianity zealously enough ${ }^{32}$-interferes with her right to ensure for her daughter an education in conformity with her own religions convictions. Based among other reasons on the mother's loss of custody rights, a failure to exhaust the local remedies on this point, and a sneer at the abrupt parental concerns with the daughter's salvation (the daughter 'has been living in the foster home during practically all of her life'), the European Commission of Human Rights deemed the complaint 'wholly unsubstantiated' ${ }^{33}$

By contrast, the Strasbourg Court did pronounce a breach of religious rights in for instance the case of Biblical Centre of the Chuvash Republic v. Russia. ${ }^{34}$ This organisation of Evangelical Christians had founded a Biblical College as well as a Sunday School. ${ }^{35}$ While the organisation was in existence for more than 15 years, and while these schools had been operating without interruption for more than 11 years, the umbrella organisation of the Biblical Centre was forcefully dissolved following certain health and safety inspections at the schools. The Strasbourg Court finds fault with virtually every aspect of this 'harsh measure. ${ }^{36}$ First and foremost, the measure was neither necessary nor proportionate: the Russian Government admitted that the health and safety violations detected were technical and minor and could easily have been remedied if the Centre would have been given time. However, such time was not granted since the Biblical Centre was dissolved almost immediately. The ECtHR furthermore detects much uncertainty in the domestic Russian jurisprudence on this type of church-run schools, which occasionally must be state-licensed under the Russian education laws and occasionally not. While in the present case apparently a license was required even for the Sunday School, the Strasbourg Court tracked down a case before the Russian Supreme Court, sitting in a formation which included two out of the three judges who approved in the present case the dissolution of the Biblical Centre, in which it held that teaching religion in this type of Sunday school-construction fell

\footnotetext{
31 Cecilia and Lisa Eriksson v. Sweden, para. 16.

32 Cecilia and Lisa Eriksson v. Sweden, para. 104.

33 Cecilia and Lisa Eriksson v. Sweden, paras. 225-226.

34 Biblical Centre of the Chuvash Republic v. Russia, Application No. 33203/o8, judgement of 12 June 2014.

35 As this case goes beyond the realm of formal education it is hence chiefly assessed by the Court through the lens of Article 9.

36 Biblical Centre of the Chuvash Republic v. Russia, para. 54.
} 
outside the scope of the Russian Education Act and was hence not subject to state-licensing. ${ }^{37}$ From other aspects of the domestic prosecutorial and judicial proceedings, too, the Strasbourg Court goes as far as stating that the 'domestic authorities revealed their determination in seeking to put an end to the applicant organisation's existence. ${ }^{38}$ The Strasbourg Court determined, accordingly, a violation of Article 9 interpreted in the light of Article 11 (freedom of association).

In addition to judgements on the precise scope of rights to establish private educational facilities, another bone of contention has proven to be state funding of such facilities and especially the lack thereof. While PI-2 has been declared to be applicable to both the contexts of public and private schooling, the fact remains that this provision does not indicate whether the state should bear the costs of non-public teaching. At the time of ratification, therefore, some states wished to be certain on this point and deposited reservations to the effect that PI-2 shall be interpreted by them as not imposing an obligation upon states to publicly fund private denominational schooling. ${ }^{39}$ Interestingly, The Netherlands declared the exact opposite: 'In the opinion of the Netherlands Government, the State should not only respect the rights of parents in the matter of education but, if need be, ensure the possibility of exercising those rights by appropriate financial measures' ${ }^{40}$ This generous declaration could straightforwardly be made insofar as it reflects Dutch constitutional principles, ${ }^{41}$ but the statement rather camouflages the fact that this position was the result of intense political debates for many decades (dramatically referred to as the "School Struggles" in Dutch political history).

In the Belgian Linguistics Case, the ECtHR affirmed that no duty can be inferred from the Convention for states to subsidize private education, ${ }^{42}$ something reiterated in other cases. ${ }^{43}$ This interpretation is certainly not out

Biblical Centre of the Chuvash Republic v. Russia, para. 56 .

Biblical Centre of the Chuvash Republic v. Russia, para. 57.

To that effect, see declarations/reservations by Azerbaijan, Bulgaria, Georgia, Germany, Moldova, and Romania.

Declaration contained in a letter from the Permanent Representative of the Netherlands, dated 29 November 1955, handed to the Secretary General at the time of deposit of the instrument of ratification, on 31 August 1954.

Article 23, para. 7, of the Constitution of the Kingdom of The Netherlands.

Belgian Linguistics Case, at Section B ('Interpretation adopted by the Court), stating that there is no obligation 'to establish at their own expense, or to subsidise, education of any particular type or at any particular level.'

E.g. X. v. United Kingdom, Application No. 7782/77, admissibility decision of the European Commission of Human Rights of 2 May 1978, at 'The Law': 'there is no positive obligation on the State, in relation to the second sentence of Article 2, to subsidise any particular 
of line with other international monitoring bodies, for instance the UN Human Rights Committee, which has considered that the ICCPR 'does not oblige States parties to fund schools which are established on a religious basis'.44 In Waldman v. Canada the Human Rights Committee went on to say, however, that if a State party chooses to provide public funding to religious schools, it should make this funding available without discrimination. This means that providing funding for the schools of one religious group and not for another must be based on reasonable and objective criteria'. ${ }^{45}$ In that particular case, the Committee found that the funding of Roman Catholic schools compared to other faith schools was in fact discriminatory under the ICCPR.

While the Strasbourg Court on paper makes use of comparable tests of "reasonableness" and "objectivity" when assessing distinctive treatment in the area of state funding for schools, it appears that the Strasbourg watchdog is rather less strict in this regard than its UN counterpart. Accordingly, in $X$. v. United Kingdom the former European Commission on Human Rights pays ample lipservice to similar principles of non-discrimination in the context of state funding of denominational schooling, stating that while it is clear that Article 2 of the First Protocol does not give rise to an obligation to subsidise any particular type of education, Article 14 would require that the authorities do not discriminate in the provision of available financial subsidies' ${ }^{6}$ It then moves on to conclude that it is neither unreasonable nor disproportionate that in Northern Ireland state schools received more funding than private educational establishments. While a sensible - if circular — conclusion in its own right, this decision does in no way do justice to the precise complaint raised by the applicant, which was in fact to the effect of claiming that while certain schools are nominally treated as private (Catholic) and others as state ones, the latter ones actually were formerly Protestant schools and fully remained 'under that religious influence. ${ }^{47}$ Accordingly, the whole public/private labelling actually served as a covert funding scheme privileging Protest denomination schooling over Catholic denomination schooling. At no point did the Commission engage with that salient allegation.

form of education in order to respect the religious and philosophical beliefs of parents.' See also W. and D.M., M. and H.I. v. United Kingdom, at 'The Law', for a similar formulation.

44 Waldman v. Canada, Communication No. 694/1996, Views of the Human Rights Committee adopted on 5 November 1999, para. 10.6.

45 Ibid.

$46 \quad$ X. v. United Kingdom, Application No. $7782 / 77$, admissibility decision of the European Commission of Human Rights of 2 May 1978, at 'The Law'.

$X$. v. United Kingdom, at 'Summary of the facts'. 
Similarly, when a private school based on a non-religious yet special didactical concept (Schülerschule) challenged before the European Commission of Human Rights Austria's state funding system, with which Austria funds "church schools" (which in practise means that more than 90\% of the state-funded denominational schools are run by the Roman Catholic Church), its complaint was deemed ill-founded. ${ }^{48}$ More particularly, the Commission found it objective and reasonable that under its Private School Act of 1964 the state grants subsidies to private schools if such a school 'corresponds to a need of the community'49 While on its face this seems an objective enough criterion, the manner in which it is interpreted by the Commission in this case illustrates perfectly how such an open-ended caveat may foster arbitrary distinctions made between different conceptions of the good: "The Commission draws ... the conclusion that to treat church schools ... differently from the applicant association's school ... is a matter which can be justified in terms of Article 14 (Art. 14) of the Convention because the church schools are so widespread that if the educational services which they provide fell to be met by the State, there would be a considerable burden on the State as it would have to make up the shortfall in schools. ${ }^{50}$ This strikes as a weak reasoning. As long as the state funds one religious denomination at the exclusion of others to run schools, it is the state which makes itself dependable upon that church (here the Roman Catholic Church), but such a pact between the state and the predominant church hardly makes it justified to structurally reject the entry into the private educational sector by other potential players.

\section{3}

\section{Conclusion}

The jurisprudence of the Strasbourg Court has generally strongly supported parental rights not to send their child to state-organized schools and to establish or avail of private, denominational schooling instead. In this area of private schooling, the Strasbourg Court could build a stronger body of jurisprudence against discriminatory funding policies. The Court is right in seeing no state duty to fund denominational schools, but where intricate funding policies serve to privilege the state or dominant religion and their schools, at the disadvantage of minority religion schools, the Court should come into action.

\footnotetext{
48 Verein Gemeinsam Lernen v. Austria, Application No. 23419/94, admissibility decision of the European Commission of Human Rights of 6 September 1995.

5o Verein Gemeinsam Lernen v. Austria, at 'The Law'.
} 